\title{
Molecular Targets for the Treatment of Metastatic Colorectal Cancer
}

\author{
Romain Cohen*(D), Thomas Pudlarz, Jean-François Delattre, Raphaël Colle and Thierry André \\ Department of Medical Oncology, Hôpital Saint-Antoine, Sorbonne Université, Assistance Publique-Hôpitaux \\ de Paris (AP-HP), F-75012 Paris, France \\ * Correspondence: romain.cohen@aphp.fr; Tel.: +33-1-49-28-23-36
}

Received: 15 July 2020; Accepted: 10 August 2020; Published: 20 August 2020

\begin{abstract}
Over the past years, colorectal cancer (CRC) was subtyped according to its molecular and genetic characteristics, allowing the development of therapeutic strategies, based on predictive biomarkers. Biomarkers such as microsatellite instability (MSI), RAS and BRAF mutations, HER2 amplification or NTRK fusions represent major tools for personalized therapeutic strategies. Moreover, the routine implementation of molecular predictive tests provides new perspectives and challenges for the therapeutic management of CRC patients, such as liquid biopsies and the reintroduction of anti-EGFR monoclonal antibodies. In this review, we summarize the current landscape of targeted therapies for metastatic CRC patients, with a focus on new developments for EGFR blockade and emerging biomarkers (MSI, HER2, NTRK).
\end{abstract}

Keywords: colorectal cancer; NTRK; HER2; BRAF; microsatellite instability; ctDNA

\section{Introduction}

Colorectal cancer (CRC) is the third most common cancer and the second leading cause of death worldwide [1]. Median overall survival (OS) in patients with previously untreated and unresectable advanced colorectal (CRC) cancer now ranges from 25 to 30 months, when combining molecular targeted therapies and chemotherapy [2].

Whereas treatment for localized CRC rely on surgery and chemotherapy, therapeutic strategies in metastatic setting were improved through the development of biomarkers for targeted therapies, such as EGFR (epithelial growth factor receptor) inhibitors, $B R A F$ serine/threonine-protein kinase B-Raf) inhibitors, HER2 (human epidermal growth factor receptor 2) inhibitors, immune checkpoint inhibitors, or NTRK (neurotrophic tyrosine receptor kinase) inhibitors. Predictive biomarkers for mCRC patients now include RAS (Kirsten rat sarcoma virus) and BRAF mutations, microsatellite instability (MSI) and mismatch repair deficiency (dMMR), HER2 amplifications and NTRK fusions. The challenge is now to implement these innovations in daily practice.

In this review, we discuss current predictive biomarkers for $\mathrm{mCRC}$ patients and their associated targeted therapy, including emerging parameters for anti-EGFR agents, such as primary tumor sidedness and longitudinal follow-up using circulating tumor DNA (ctDNA), immune checkpoint inhibitors for MSI/dMMR tumors, new developments for $B R A F^{\mathrm{V} 600 \mathrm{E}}$-mutated cancers, anti-HER2 treatments and NTRK inhibitors.

\section{RAS/RAF Wild-Type Tumors and Anti-EGFR Agents}

\subsection{Predictive Factors for The Efficacy of Anti-EGFR Agents}

Activating mutations of KRAS and NRAS are predictive of resistance to anti-EGFR agents in CRC patients (see Figure 1) [3]. KRAS is mutated in 40 to $50 \%$ of CRC and NRAS in 4 to $8 \%$ [4]. 
Recommendations for RAS mutation testing include KRAS exons 2, 3, and 4 (codons 12, 13, 59, 61, 117, and 146) and NRAS exons 2,3, and 4 (codons 12,13,59,61, and 117) [5,6]. Patients with KRAS/NRAS wild type (WT) are eligible to treatments targeting the EGFR.

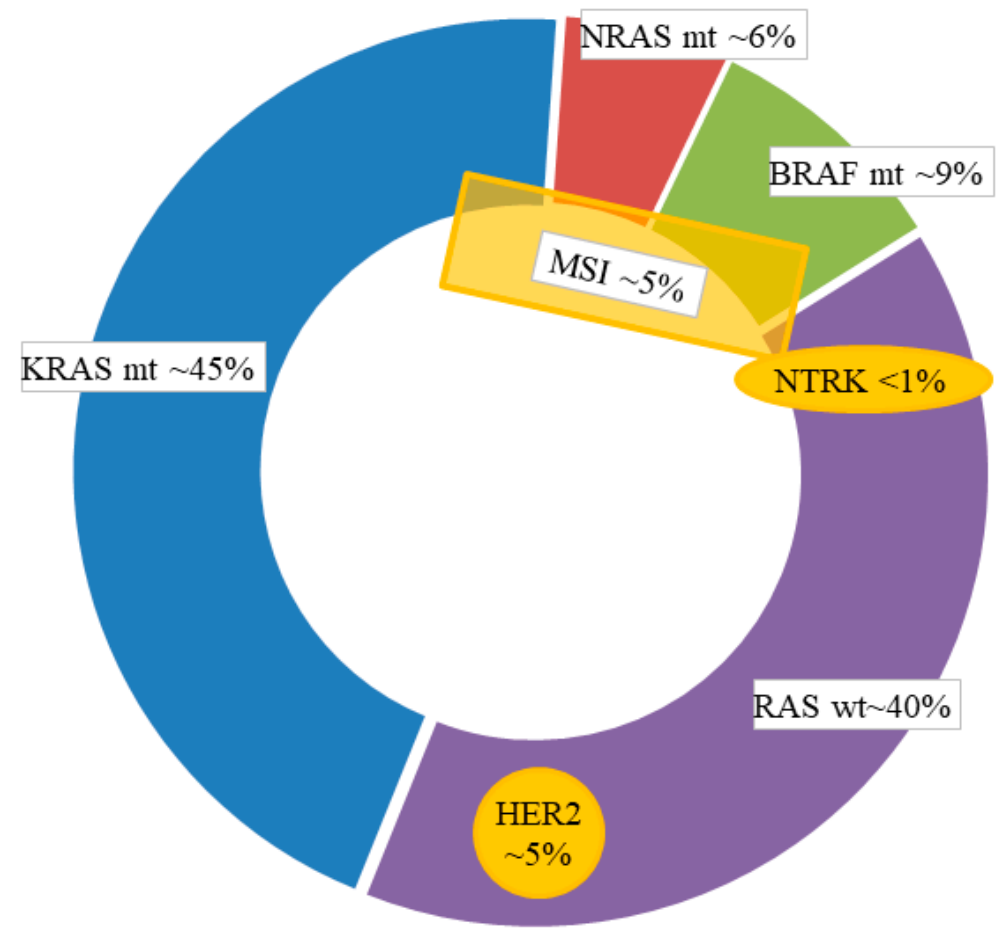

Figure 1. Molecular targets in metastatic colorectal cancer.

Other mechanisms of resistance are described. These might involve the EGFR itself with mutations of the EGFR ectodomain [7]. It can also be related to the overactivation of a protein downstream from the EGFR in the MAPK (mitogen-activated protein kinase) pathway, such as BRAF [8], although the $B R A F^{\mathrm{V} 600 \mathrm{E}}$ hotspot mutation was not formally demonstrated as a factor of resistance to anti-EGFR agents (see below). The constitutional activation of the PI3K/Akt/mTOR pathway through PIK3CA exon 20 mutation or PTEN loss, could participate in resistance to monoclonal antibodies (mAbs) $[9,10]$. Furthermore, amplifications of HER2, HER3, or MET and HER2 activating mutations seem associated with resistance to anti-EGFR therapy [11]. Recent reports brought to light the predictive value of the micro RNA miR-31-3p. Mir-31 plays a significant role in activating the $R A S$ signaling pathway, and high miR-31-3p expression could be the witness of the tumor's EGFR independency and subsequently to its resistance to anti-EGFR therapy. Several post hoc analysis of randomized trials showed the level of expression of miR-31-3p is a valid biomarker of anti-EGFR efficacy [12-14].

\subsection{Current Management of Anti-EGFR Therapy}

First, anti-EGFR mAbs do not improve outcomes as adjuvant treatment for resected stage III colon cancer [15]. Concerning patients with resectable $\mathrm{mCRC}$, a warning signal concerning the use of anti-EGFR mAbs in the peri-operative setting was raised by the NEW EPOC trial. This study showed a detrimental effect of cetuximab, both on disease free survival (DFS) and overall survival (OS), when added to chemotherapy [16]. Although anti-EGFR mAbs should not be used as perioperative treatment for patients with resectable $\mathrm{mCRC}$, these treatments could be useful as a converting therapy to shrink potentially resectable metastatic diseases [17].

Anti-EGFR mAbs (cetuximab and panitumumab) are associated with improved response rates, progression free survival (PFS), and OS in first-line setting, when combined with an oxaliplatin-based or irinotecan-based regimen, as well as in second or latter lines alone, or combined with cytotoxic 
agents [18-29]. Although the NORDIC VII and COIN studies did not show a significant effect of cetuximab in combination with an oxaliplatin-based regimen [30,31], recent data provided by the TAILOR trial demonstrate that it can be safely prescribed with FOLFOX for RAS WT mCRC patients [32]. There is no direct comparison between panitumumab and cetuximab, except for chemo-resistant patients with the ASPECCT trial that showed the non-inferiority of panitumumab in patients with chemotherapy-refractory KRAS WT (exon 2) mCRC [33].

\subsection{Primary Tumor Sidedness}

Primary tumor sidedness (PTS) seems to play a decisive role in the sensitivity to anti-EGFR mAbs. Indeed, there is growing evidence showing that the PTS is a prognostic factor in the RAS WT population, as well as a predictive factor of response to anti-EGFR mAbs [34]. A retrospective analysis of six randomized trials (CRYSTAL, FIRE-3, CALGB 80405, PRIME, PEAK, and 20050181) showed poorer outcomes (response rates, PFS, OS) for right-sided tumors, compared to left-sided tumors. This analysis also showed a predictive effect of PTS, with a greater effect of chemotherapy plus anti-EGFR mAbs, compared to chemotherapy \pm bevacizumab in patients with left-sided tumors [35]. A recent retrospective analysis of the ARCAD database showed that the prognostic value of PTS was restricted to the KRAS WT population and confirmed the predictive value of PTS for cetuximab efficacy, with improved outcomes for left-sided mCRC patients [36]. On the contrary, patients with RAS WT right-sided $\mathrm{mCRC}$ seem to derive limited benefit from anti-EGFR treatments.

Although these results should be interpreted with caution due to their retrospective nature, they suggest that one should use anti-EGFR mAbs plus chemotherapy as the first line treatment only in patients with KRAS/NRAS WT and left-sided tumors, and might prefer chemotherapy plus an antiangiogenic agent for patients with right-sided mCRC [37]. Nevertheless, it is worth noting the optimal sequence with anti-EGFR mAbs in patients with RAS WT mCRC in the context of PTS, remains unclear. Multi-line therapy trials such as the STRATEGIC-1 phase III study (NCT01910610) would provide valuable information.

\subsection{Rechallenge and Liquid Biopsies}

Resistance to targeted therapies such as anti-EGFR mAbs emerges through the selection of tumor clones harboring an innate mutation of resistance. When the anti-EGFR mAb is interrupted, the selecting pressure on the sensitive clones is withdrawn and the tumor can regain sensitivity to the targeted therapy (see Figure 2). Several strategies can be used to overcome tumor resistance (rechallenge, reintroduction, sequential therapy, dose intensification), and rechallenge seems to be the most promising in the context of anti-EGFR mAbs [38]. Rechallenge of anti-EGFR therapy could be defined as retreatment after a progression while on treatment, for a tumor that initially displayed sensitivity to the therapy [39].

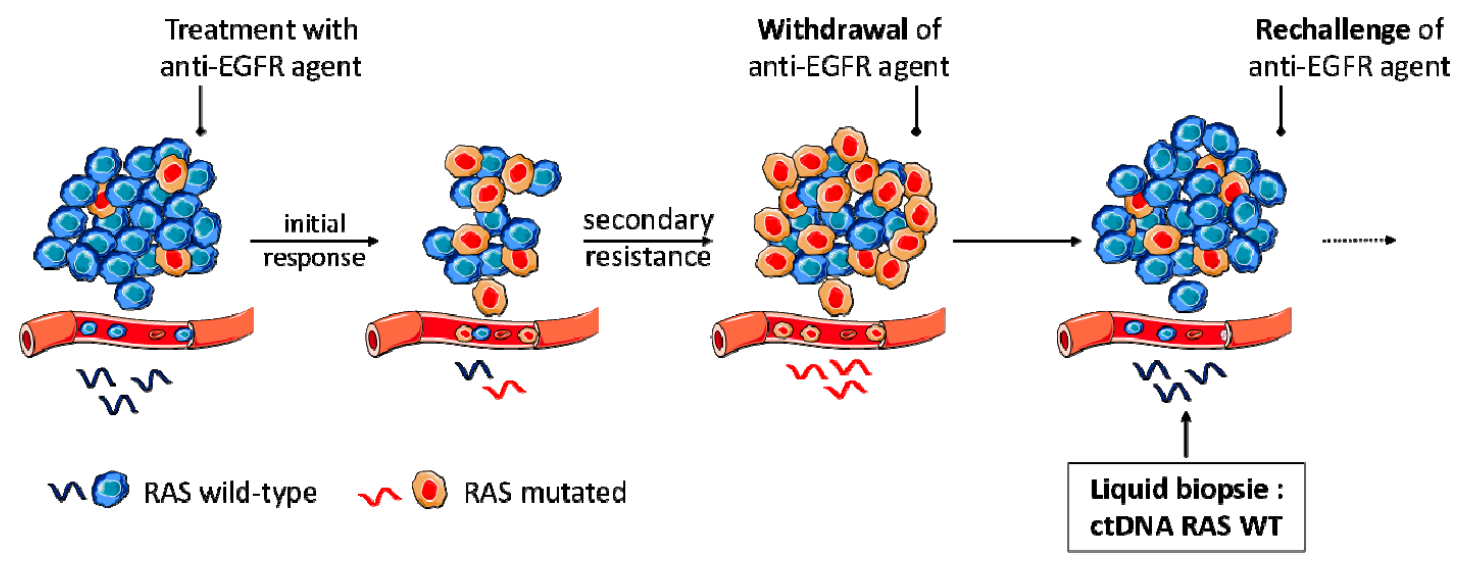

Figure 2. Rechallenge of anti-EGFR agents. 
Longitudinal follow-up of mutant clones seems particularly seductive for rechallenge strategies. Studies with longitudinal monitoring of ctDNA showed that $R A S$ mutant clones arise in blood during anti-EGFR therapy and decline exponentially upon withdrawal of treatment, with a half-life of 4 to 5 months [40]. The CRICKET phase II study $(n=38)$ was the first prospective demonstration that a rechallenge strategy with cetuximab and irinotecan might be active in RAS/BRAF WT mCRC patients with acquired resistance to cetuximab. No RAS mutation was detected in blood samples from patients who experienced partial response [41,42]. Several clinical trials are currently evaluating the use of liquid biopsy in the context of anti-EGFR rechallenge (CHRONOS, NCT03227926; RASINTRO, NCT03259009) [41].

\section{3. $B R A F^{\mathrm{V} 600 \mathrm{E}}$ Mutation and Targeted Therapies}

$B R A F^{\mathrm{V} 600 \mathrm{E}}$ mutation, found in approximately $8-10 \%$ of mCRC (see Figure 1), induces am RAS-independent constitutional activation of the MAPK pathway, leading to cell proliferation and survival, and is associated with poor prognosis [43]. Although some BRAF mutations occur beyond the V600 hotspot, representing $22 \%$ of all BRAF mutations in CRC, they do not have the same biological, clinical, and therapeutic consequences as the ${ }^{\mathrm{V} 600 \mathrm{E}}$ mutation [44]. These BRAF non- ${ }^{\mathrm{V} 600 \mathrm{E}}$ mutated tumors are more likely to be left-sided, with a lower grade of differentiation, and associated with better prognosis and resistance to $B R A F$ inhibitors, although some might be sensitive to EGFR $[45,46]$. To note, fusions of the BRAF gene were also reported. These genetic alterations are associated with right-sided tumors and seem to confer resistance to anti-EGFR therapy $[11,47,48]$.

$B R A F^{\mathrm{V} 600 \mathrm{E}} \mathrm{CRC}$ patients are more likely to be older, female, with right-sided tumors harboring mucinous component, associated with peritoneal and distant lymph node metastases but less pulmonary metastases [49]. Importantly about $20 \%$ of $B R A F^{\mathrm{V} 600 \mathrm{E}}$ CRC exhibit the MSI phenotype, which is predictive for the efficacy of immune checkpoint inhibitors, whatever the $B R A F$ mutational status (see below) [43,50].

$B R A F^{\mathrm{V} 600 \mathrm{E}} \mathrm{mCRC}$ patients have a lower probability to receive second-line treatments than the $B R A F$ WT population. As a matter of fact, intensification strategies seem effective for these patients [51-53]. In the TRIBE study, first-line FOLFOXIRI (folinic acid, fluorouracil, oxaliplatin, and irinotecan) plus bevacizumab was associated with a non-significant improvement of overall survival for $B R A F^{\mathrm{V} 600 \mathrm{E}}$ mutants, compared to FOLFIRI (folinic acid, fluorouracil, and irinotecan) plus bevacizumab $(n=28)$ [54]. Despite the small population sample of this subgroup analysis, FOLFOXIRI-bevacizumab is considered to be a valid option for chemotherapy-naïve patients with $B R A F^{\mathrm{V} 600 \mathrm{E}} \mathrm{mCRC}$. Importantly, no survival benefit was reported for $B R A F^{\mathrm{V} 600 \mathrm{E}}$ patients in the subsequent TRIBE2 phase III trial, which tested FOLFOXIRI plus bevacizumab and reintroduction, upfront after progression, versus mFOLFOX6 plus bevacizumab, followed by FOLFIRI plus bevacizumab (33 patients in each arm) [55]. The triplet chemotherapy regimen, associated with either bevacizumab or cetuximab, is currently being tested in the AIO-KRK-0116 phase II trial (NCT04034459; see Table 1).

Table 1. Ongoing clinical trials for patients with $B R A F^{\mathrm{V} 600 \mathrm{E}}$ metastatic colorectal cancer.

\begin{tabular}{|c|c|c|c|c|}
\hline Therapy & Phase & Condition & Primary Endpoint & NCT Identifier \\
\hline Encorafenib $^{1}+$ cetuximab $^{2}+$ nivolumab $^{4}$ & $1 / 2$ & 2 or 3rd line & ORR, DLT & NCT04017650 \\
\hline Encorafenib $^{1}+$ binimetinib $^{3}+$ nivolumab $^{4}$ & $1 / 2$ & >1st line & ORR, DLT & NCT04044430 \\
\hline Dabrafenib $^{1}+$ trametinib $^{3}+$ PDR $001^{4}$ & 2 & Any line & ORR, DLT & NCT03668431 \\
\hline FOLFOXIRI + cetuximab ${ }^{2}$ or bevacizumab 5 & 2 & 1st line & ORR & NCT04034459 \\
\hline FOLFIRI + cetuximab ${ }^{2}+$ vemurafenib $^{1}$ & 2 & - & ORR & NCT03727763 \\
\hline Irinotecan + AZD $1775^{6}$ & 1 & $>$ 1st line & DLT & NCT02906059 \\
\hline Panitumumab ${ }^{2}+$ trametinib $^{3}$ & 2 & $>2$ nd line & ORR & NCT03087071 \\
\hline
\end{tabular}




\subsection{Antiangiogenic Agents for the BRAF ${ }^{V 600 E}$ Mutants}

There is currently no predictive biomarker for the efficacy of antiangiogenics in the overall population of mCRC patients, and the activity of these agents are not specifically proven among BRAF ${ }^{\mathrm{V} 600 \mathrm{E}} \mathrm{mCRC}$ patients. The AVF2107g35 and AGITG MAX36 trials showed no survival improvement by adding bevacizumab to first-line IFL (bolus irinotecan, fluorouracil, and folinic acid) or capecitabine $[56,57]$. Yet, the RAISE study (FOLFIRI \pm ramucirumab) and the VELOUR trial (FOLFIRI \pm aflibercept) showed that the subset of $B R A F^{\mathrm{V} 600 \mathrm{E}} \mathrm{CCR}$ tended to benefit from these antiangiogenics in second line, although the small size of the cohorts precluded statistical significance $[58,59]$. All in all, these retrospective analyses suggest that antiangiogenics could be beneficial to $B R A F^{\mathrm{V} 600 \mathrm{E}} \mathrm{mCRC}$ patients, in the first-line or latter [60].

\subsection{Anti-EGFR Agents for BRAF ${ }^{V 600 E}$ Mutants}

Data regarding the efficacy of anti-EGFR therapies for $B R A F^{\mathrm{V} 600 \mathrm{E}}$ patients are not clear, either as single agent or in combination with chemotherapy. Two meta-analyses were performed. A meta-analysis performed by Pietrantonio et al. suggested that anti-EGFR agents are not effective for $B R A F^{\mathrm{V} 600 \mathrm{E}}$ patients [61]. However, another meta-analysis by Rowland et al. failed to detect any significant difference in the effect of anti-EGFR agents between the BRAF ${ }^{\mathrm{V} 600 \mathrm{E}}$ and $B R A F \mathrm{WT}$ population [62]. Additionally, a retrospective analysis of the $B R A F^{\mathrm{V} 600 \mathrm{E}}$ subgroup, the FIRE-3 study (first-line FOLFIRI plus cetuximab versus FOLFIRI plus bevacizumab in KRAS WT mCRC patients) identified a higher response rate in the cetuximab arm [63]. Moreover, a recent study (VOLFI AIO KRK0109) comparing the efficacy of first line FOLFOXIRI with or without panitumumab, found a significant increase in objective response in the subgroup of $B R A F^{\mathrm{V} 600 \mathrm{E}}$ patients $(71 \%$ versus $22 \%$, $n=14$ ) [18]. the positive results of the BEACON study also confirm that anti-EGFR agents are valuable for the $B R A F^{\mathrm{V} 600 \mathrm{E}}$ population (see below) [64]. International guidelines did not contraindicate anti-EGFR agents for $B R A F^{\mathrm{V} 600 \mathrm{E}} \mathrm{mCRC}$ patients $[6,37]$.

\subsection{BRAF Inhibitors}

In contrast to melanoma, $B R A F$ inhibitors as single agents were associated with disappointing results. One hypothesis is that $B R A F$ inhibition induces feedback EGFR activation and might promote MAPK constitutive signaling. EGFR-mediated reactivation of downstream signaling pathways contributes to the inherent resistance of these tumors to BRAF inhibitor monotherapy [65]. With this issue in mind, several combinations of BRAF inhibitor, anti-EGFR agents, PI3K inhibitors, or MEK inhibitors were tested, with interesting results [66-70]. These studies supported the design of the phase III BEACON study, which evaluated encorafenib and cetuximab \pm binimetinib versus chemotherapy (investigator choice regimen of cetuximab plus irinotecan or FOLFIRI). $665 B R A F^{\mathrm{V} 600 \mathrm{E}} \mathrm{mCRC}$ patients with disease progression after one or two previous lines were randomized. Median OS was 9.3 months in the triplet and the doublet experimental arms, compared to 5.9 months in the control arm ( $\mathrm{HR}=0.60$, $95 \%$ confidence interval $0.47-0.75$ and $\mathrm{HR}=0.61,95 \%$ confidence interval $0.48-0.77$, respectively) $[64,71]$. The objective response rate was statistically improved ( $2 \%$ in the control group, compared to $20 \%$ and $26 \%$ in the doublet and triplet group, respectively). Toxicity was manageable, with grade 3 or higher toxicities being comparable between the three arms, with gastrointestinal and skin-related events occurring in the experimental groups. A complementary quality of life analysis found a reduced risk of quality of life deterioration by more than $40 \%$ in both the doublet and the triplet group [72]. Although the study was not designed to compare the two experimental arms, the benefit-risk balance might be in favor of the encorafenib plus cetuximab combination, without the MEK inhibitor.

\section{RAS Mutants and Targeted Therapies}

Approximately $50 \%$ of $\mathrm{mCRC}$ are reported to have KRAS/NRAS pathogenic mutation. The treatment of these tumors of poor prognosis was proven to be highly challenging. They are 
intrinsically resistant to anti-EGFR mAbs (see above). Antiangiogenics (bevacizumab, aflibercept, ramucirumab) seem to be effective in this population but predictive biomarkers for the efficacy of these compounds are lacking $[59,73,74]$.

$K R A S^{\mathrm{G} 12 \mathrm{D}}$ (glycine 12 to aspartic acid) is the most common KRAS mutation in colorectal cancer. A new generation of KRAS inhibitor might be a game changer for this population [75]. Recently, promising results of a direct $K R A S^{\mathrm{G} 12 \mathrm{C}}$ inhibitor were reported. AMG 510 is a novel small molecule that specifically and irreversibly inhibits $K R A S^{\mathrm{G} 12 \mathrm{C}}$, by locking it in an inactive guanosine diphosphate (GDP)-bound state. In the first in-human study evaluating AMG 510 in adult patients with locally advanced or metastatic KRAS ${ }^{\mathrm{G} 12 \mathrm{C}}$ mutant solid tumors (CodeBreak-100; NCT03600883), ORR and DCR were $12.0 \%(3 / 25)$ and $80.0 \%(20 / 25)$, in patients with $K R A S^{\mathrm{G} 12 \mathrm{D}}$-mutated mCRC [76]. Further confirmation is needed.

\section{Microsatellite Instability and Immune Checkpoint Inhibitors}

\subsection{Colorectal Cancers, Mismatch Repair Deficiency, and Microsatellite Instability}

While most CRCs develop via the chromosomal instability pathway (aneuploidy and loss of genetic material), $10-15 \%$ of them arise from the microsatellite instability (MSI) pathway. MSI is caused by the deficiency of the DNA mismatch repair (dMMR) system, resulting from a germline mutation in MMR genes (MLH1, PMS2, MSH2, MSH6) predisposing to Lynch syndrome or from an epigenetic inactivation of $M L H 1$ (i.e., sporadic cancers). These sporadic cases are frequently associated with the $B R A F^{\mathrm{V} 600 \mathrm{E}}$ mutation [77]. MSI/dMMR is observed in approximately $10-15 \%$ of localized CRC and $4-5 \%$ of mCRC (see Figure 1) [43,78]. MSI/dMMR CRCs mainly arise from the proximal colon and display specific features such as poor differentiation, abundant tumor-infiltrating lymphocytes, and particular patterns of metastatic spread with frequent distant lymph node metastases and peritoneal involvement [49]. In localized CRC, MSI/dMMR is associated with favorable prognosis [79,80]. Data are more controversial in metastatic setting. Still, the available literature suggests MSI/dMMR mCRC are less responsive to conventional chemotherapy, compared to microsatellite stable/MMR-proficient (MSS/pMMR) tumors [43,81-83].

MSI/dMMR CRCs are characterized by a high tumor mutational burden (i.e., hypermutated phenotype) with highly immunogenic neoantigens arising from frameshift mutations that induce high infiltration through activated cytotoxic T CD8+ lymphocytes [84-86]. However, MSI/dMMR neoplasms upregulates immune checkpoints that protects MSI cancer cells from their hostile immune micro-environment [87,88].

\subsection{Targeting the Immune System}

MSI/dMMR has emerged as a major predictive biomarker for the efficacy of ICIs, especially for mCRC patients. While pMMR/MSS CRCs are mainly resistant to ICIs (i.e., cold tumors), MSI/dMMR tumors were associated with high sensitivity to immunotherapy (i.e., hot tumors). The activity of ICIs for patients with chemoresistant MSI/dMMR mCRC was demonstrated in several phase II trials, with objective response rates ranging from $33 \%$ to $58 \%$ and 12 -month PFS rates between $31 \%$ and $71 \%$ [50,89-94]. Importantly, results of the non-randomized CheckMate-142 trial suggest that combinations of anti-PD1 and anti-CTLA4 mAbs might be more effective than anti-PD1 or anti-PDL1 agents alone. Pembrolizumab and nivolumab +/- ipilimumab are approved by the Food and Drug Administration, for the treatment of patients with MSI/dMMR mCRC, who progressed after fluoropyrimidine, oxaliplatin, and irinotecan-based treatment.

The efficacy of ICIs was also demonstrated as front-line treatment for patients with chemotherapy-naive MSI/dMMR mCRC. In a third cohort of the CheckMate-142 trial, 45 patients were treated with nivolumab plus ipilimumab as the first-line treatment. ORR was 77\%, the 1-year PFS estimate was 77\% [95]. Of major importance, the phase III KEYNOTE-177 trial recently showed pembrolizumab monotherapy to be superior to standard of care first-line chemotherapy (investigator's 
choice of FOLFOX or FOLFIRI, with or without bevacizumab or cetuximab) in terms of PFS for MSI/dMMR mCRC patients. Medians of PFS were 16.5 months versus 8.2 months (HR $=0.60,95 \% \mathrm{CI}$ $0.45-0.80$ ). The 12 - and 24 -month PFS rates were $55 \%$ and $48 \%$ with pembrolizumab versus $37 \%$ and $19 \%$ with chemotherapy. It is highly likely that pembrolizumab will become the standard of care for patients with newly diagnosed MSI/dMMR mCRC [96].

ICIs are currently evaluated for patients with localized MSI/dMMR colon cancer. The NICHE phase II study paved the way for their development in this setting and might refine therapeutic strategies for early-stage MSI/dMMR CC [97]. Indeed, in this trial testing nivolumab plus ipilimumab as neoadjuvant treatment, all 21 dMMR CC patients had a pathological response, with $95 \%$ of major responses including 12 complete pathological responses. These impressive results highlight neoadjuvant immunotherapy as a promising strategy that warrants further research. ICIs are also evaluated in combination with adjuvant chemotherapy for stage III MSI/dMMR colon cancer patients-the ATOMIC trial (NCT02912559; FOLFOX +/- atezolizumab), and the POLEM trial (NCT03827044; 24 weeks of single agent fluoropyrimidine chemotherapy or 12 weeks of oxaliplatin-based chemotherapy $+/-$ avelumab) [28].

\subsection{Predictive Biomarkers among MSI/dMMR CRC Patients Treated with Immunotherapy}

There is currently no robust predictive biomarker for the efficacy of ICIs among MSI/MMR CRC patients. Despite the high clinical activity of ICIs in this population, some patients do not benefit from these treatments, and there is currently no clear explanation for these cases of primary resistance. It is noteworthy that misdiagnosis of MSI/dMMR status is responsible for a significant amount of cases with primary resistance to ICIs $[98,99]$.

First, MSI/dMMR tumors harboring the $B R A F^{\mathrm{V} 600 \mathrm{E}}$ mutation seem to be quite sensitive to MSI/dMMR BRAF WT diseases [50]. Second, PD-1 expression, beta-2-microglobulin mutations, and major histocompatibility complex class I expression were not found to be associated with resistance to ICI $[50,90,100]$. Loss-of-function mutations in Janus kinases JAK1/2 might lead to primary resistance of MSI/dMMR mCRC to ICI [101]. Interestingly, the tumor mutational load was reported to predict ICI efficacy in 2 small cohort studies ( $<33$ patients) $[102,103]$. Data are also emerging for the predictive impact of the immune infiltrate for the efficacy of ICIs. Indeed, in a recent work by Loupakis and colleagues, the level of T cell infiltration was linked to better response, PFS, and OS [98]. All these results deserve confirmation in larger prospective studies.

\section{HER2 and Anti-HER2 Agents}

Approximately $1 \%$ to $8 \%$ of CRC harbor HER2 gene amplification (see Figure 1) [104-107]. HER2 overexpression is associated with distal cancers, with a frequency of $4.3-5.4 \%$ for rectal cancers, and KRAS WT status, although these 2 genetic alterations could be observed together $[106,108,109]$. While the prognostic significance of HER2 amplifications is controversial, many arguments are accumulating in favor of a negative predictive value of HER2 amplifications for anti-EGFRs efficacy (ORR, PFS, OS) [11,110,111].

The diagnostic method for HER2 testing in CRC was standardized by the Heracles diagnostic criteria, with first-line immunohistochemistry (IHC) analysis followed, if appropriate, by FISH analysis (fluorescence in situ hybridization). Positivity is defined by an IHC $3+$ score or an IHC $2+$ score associated with FISH positivity [112].

Evidence is growing for the efficacy of anti-HER2 agents for patients with HER2-positive mCRC. Combinations of trastuzumab plus lapatinib, trastuzumab with pertuzumab, and trastuzumab plus tucatinib were tested in phase II studies (Heracles-A, MyPathway, and Mountaneer, respectively). They showed promising response rates of 30 and 32, and a 55\% and median PFS of 4.7, 2.9, and 6.2 months, respectively $[109,113,114]$. Patients with HER2-positive and KRAS-mutated mCRC were excluded from the Mountaneer and Heracles-A trials, but it is worthy to note that one HER2-positive and KRAS-mutated mCRC patient experienced an objective response in the MyPathway 
study $[109,113,114]$. In contrast, the Heracles-B trial, with the association of pertuzumab and trastuzumab emtansine, failed to reach its primary endpoint (ORR), even if the median PFS was 4.7 months [115]. Recent report of the DESTINY-CRC01 phase II trial has brought to light trastuzumab-deruxtecan as a potential game changer. Fifty patients with chemoresistant HER2-positive mCRC were treated with this antibody-drug conjugate (composed of an anti-HER2 antibody and topoisomerase I inhibitor). The confirmed objective response rate was $45 \%$ (24/53). Even patients with prior anti-HER2 agents derived benefit from this treatment, with an objective response rate of $43.8 \%$ (7/16 pts). Two deaths from drug-related interstitial lung disease were reported.

Overall, anti-HER2 agents are highly seductive therapies for the HER2-positive population, but data from randomized trials are lacking in rigorous evaluation of their added value. The only ongoing randomized study is a phase II trial comparing trastuzumab and pertuzumab to irinotecan and cetuximab, in patients with HER2-positive RAS/RAF WT mCRC (NCT03365882).

\section{NTRK Gene Fusions and TRK Inhibitors}

NTRK gene fusions recently emerged as a highly seductive therapeutic target for cancer patients. TRK inhibitors (larotrectinib, entrectinib) demonstrated an impressive clinical activity in this population, regardless of histological type. In single-arm studies, larotrectinib showed an objective response rate of $75 \%$, with a time of response superior to 6 months in $73 \%$ of cases, and entrectinib, an ORR of $57 \%$, with a time of response superior to 6 months in $68 \%$ of cases $[116,117]$. These results led to accelerated approvals by the FDA for the treatment of refractory solid tumors with the NTRK gene fusion, whatever the tumor type.

Strategies for NTRK fusion screening are based on immunohistochemistry fluorescence in situ hybridization, RT-PCR (reverse transcription polymerase chain reaction) and next-generation sequencing, depending on the probability of NTRK fusion $[118,119]$. NTRK fusions are rare in colorectal cancers, with an incidence of $0.23-0.97 \%$ (see Figure 1) [48,120-123]. It is, therefore, necessary to select the population to be screened.

Characteristics of NTRK fusion-positive CRC patients are female, right-sided primary tumor location, RAS/RAF WT status, and MSI phenotype [121]. Intriguingly, the MSI phenotype was consistently reported in association with NTRK fusions. More precisely, these genetic alterations seemed to occur in the context of BRAF WT tumors with hypermethylation of the MLH1 gene promoter [124]. The incidence of NTRK fusions was estimated at approximately $42 \%$ in this molecularly selected population [48]. There is currently no data about the efficacy of NTRK inhibitors or immune checkpoint inhibitors in this specific biological entity.

\section{Conclusions}

Substantial advances were made in the individualization of therapeutic strategies for mCRC patients over the last 10 years. Responders to anti-EGFR therapies can be specifically selected with an enlarged panel of biomarker, and the therapeutic strategies can be optimized with the longitudinal follow-up of ctDNA. Patients with $B R A F^{\mathrm{V} 600 \mathrm{E}} \mathrm{mCRC}$, who were long left behind, now have effective therapeutic options. Beyond highly seductive but quite rare targets, such as HER2 amplification and NTRK fusions, the most striking revolution for targeted therapies in CRC patients comes from ICIs that were a breakthrough for patients with MSI/dMMR tumors. Patients' outcomes were dramatically improved, and this enforced clinicians and researchers to conceptualize CRC as at least 2 distinct diseases-the MSI/dMMR tumors, and the others (Table 2). Importantly, the development of ICIs is associated with methodological issues in relation with the pseudoprogression phenomenon and long-term survivals. This observation highlights the necessity to develop new study designs and to anticipate such issues in pre-planned statistical analyses. 
Table 2. Molecular subtypes of colorectal cancer and targeted treatment options.

\begin{tabular}{cc}
\hline Molecular Subtypes & Targeted Therapies \\
\hline MSI, whatever the $R A S / R A F$ mutational status & Immune checkpoint inhibitor(s) \\
\hline$R A S / R A F$ wild-type & Anti-EGRF mAbs \\
\hline$B R A F^{\mathrm{V} 600 \mathrm{E}}$ mutated \\
$R A S$ mutated & Encorafenib + cetuximab +/- binimetinib \\
\hline HER2 amplified/mutated & $\begin{array}{c}\text { No current targeted therapy, ongoing trials with } \\
\text { new-generation KRAS inhibitors }\end{array}$ \\
\hline NTRK fusion-positive & $\begin{array}{c}\text { Anti-HER2 mAbs/inhibitors (trastuzumab, } \\
\text { pertuzumab, lapatinib), anti-HER2 antibody-drug } \\
\text { conjugate (trastuzuab deruxtecan) }\end{array}$ \\
\hline
\end{tabular}

This evolution brings to light the international CMS classification, that clustered CRC into 4 distinct consensus molecular subtypes (CMS): CMS1 (MSI Immune), hypermutated, microsatellite unstable, $B R A F^{\mathrm{V} 600 \mathrm{E}}$ mutated, with strong immune activation; CMS2 (Canonical), epithelial, chromosomally unstable, with marked WNT and MYC signaling activation; CMS3 (Metabolic), epithelial, with evident metabolic dysregulation; and CMS4 (Mesenchymal), prominent TGF- $\beta$ activation, stromal invasion, and angiogenesis. The CMS classification might help identify new pathways to target, such as the TGF- $\beta$ pathway or others. Although it is currently used in research investigation, the role of CMS classification for therapeutic strategies remains to be defined, and its feasibility in routine practice to be demonstrated.

To conclude, translational research seems more necessary than ever to understand the biological specificities of these various types of $\mathrm{CRC}$, the innate and acquired mechanisms of resistance to targeted therapies, to bring progress to all patients.

Funding: This research received no external funding.

Conflicts of Interest: T.A. reports consulting/advisory role and or received honoraria from, Amgen, Bristol-Myers Squibb, Chugai, Clovis, Gritstone Oncology, HalioDx, Merck Sharp \& Dohme Corp, Pierre Fabre, Roche/Ventana, Sanofi, Servier, and Tesaro/GSK, and received travel, accommodations, and expenses from Roche/Genentech, MSD Oncology, and Bristol-Myers Squibb. R.C. reports honoraria from Amgen, Sanofi, and Servier, and a research grant from the Servier Institute. The other authors declare no conflict of interest.

\section{References}

1. Bray, F.; Ferlay, J.; Soerjomataram, I.; Siegel, R.L.; Torre, L.A.; Jemal, A. Global cancer statistics 2018: GLOBOCAN estimates of incidence and mortality worldwide for 36 cancers in 185 countries. CA Cancer J. Clin. 2018, 68, 394-424. [CrossRef] [PubMed]

2. Chibaudel, B.; Tournigand, C.; Bonnetain, F.; Richa, H.; Benetkiewicz, M.; André, T.; de Gramont, A. Therapeutic strategy in unresectable metastatic colorectal cancer: An updated review. Ther. Adv. Med. Oncol. 2015, 7, 153-169. [CrossRef] [PubMed]

3. Lièvre, A.; Bachet, J.-B.; Le Corre, D.; Boige, V.; Landi, B.; Emile, J.-F.; Côté, J.-F.; Tomasic, G.; Penna, C.; Ducreux, M.; et al. KRAS mutation status is predictive of response to cetuximab therapy in colorectal cancer. Cancer Res. 2006, 66, 3992-3995. [CrossRef] [PubMed]

4. Cercek, A.; Braghiroli, M.I.; Chou, J.F.; Hechtman, J.F.; Kemeny, N.; Saltz, L.; Capanu, M.; Yaeger, R. Clinical features and outcomes of patients with colorectal cancers harboring NRAS mutations. Clin. Cancer Res. 2017, 23, 4753-4760. [CrossRef]

5. Allegra, C.J.; Rumble, R.B.; Hamilton, S.R.; Mangu, P.B.; Roach, N.; Hantel, A.; Schilsky, R.L. Extended RAS gene mutation testing in metastatic colorectal carcinoma to predict response to anti-epidermal growth factor receptor monoclonal antibody therapy: American Society of Clinical Oncology Provisional Clinical Opinion update 2015. J. Clin. Oncol. 2016, 34, 179-185. [CrossRef] 
6. Van Cutsem, E.; Cervantes, A.; Adam, R.; Sobrero, A.; Van Krieken, J.H.; Aderka, D.; Aranda Aguilar, E.; Bardelli, A.; Benson, A.; Bodoky, G.; et al. ESMO consensus guidelines for the management of patients with metastatic colorectal cancer. Ann. Oncol. 2016, 27, 1386-1422. [CrossRef]

7. Parseghian, C.M.; Napolitano, S.; Loree, J.M.; Kopetz, S. Mechanisms of innate and acquired resistance to anti-EGFR therapy: A review of current knowledge with a focus on rechallenge therapies. Clin. Cancer Res. 2019, 25, 6899-6908. [CrossRef]

8. Pietrantonio, F.; Vernieri, C.; Siravegna, G.; Mennitto, A.; Berenato, R.; Perrone, F.; Gloghini, A.; Tamborini, E.; Lonardi, S.; Morano, F.; et al. Heterogeneity of acquired resistance to anti-EGFR monoclonal antibodies in patients with metastatic colorectal cancer. Clin. Cancer Res. 2017, 23, 2414-2422. [CrossRef]

9. Karapetis, C.S.; Jonker, D.; Daneshmand, M.; Hanson, J.E.; O'Callaghan, C.J.; Marginean, C.; Zalcberg, J.R.; Simes, J.; Moore, M.J.; Tebbutt, N.C.; et al. PIK3CA, BRAF, and PTEN status and benefit from cetuximab in the treatment of advanced colorectal cancer-Results from NCIC CTG/AGITG CO.17. Clin. Cancer Res. 2014, 20, 744-753. [CrossRef]

10. Jhawer, M.; Goel, S.; Wilson, A.J.; Montagna, C.; Ling, Y.-H.; Byun, D.-S.; Nasser, S.; Arango, D.; Shin, J.; Klampfer, L.; et al. PIK3CA mutation/PTEN expression status predicts response of colon cancer cells to the epidermal growth factor receptor inhibitor cetuximab. Cancer Res. 2008, 68, 1953-1961. [CrossRef]

11. Cremolini, C.; Morano, F.; Moretto, R.; Berenato, R.; Tamborini, E.; Perrone, F.; Rossini, D.; Gloghini, A.; Busico, A.; Zucchelli, G.; et al. Negative hyper-selection of metastatic colorectal cancer patients for anti-EGFR monoclonal antibodies: The PRESSING case-control study. Ann. Oncol. 2017, 28, 3009-3014. [CrossRef] [PubMed]

12. Laurent-Puig, P.; Grisoni, M.-L.; Heinemann, V.; Liebaert, F.; Neureiter, D.; Jung, A.; Montestruc, F.; Gaston-Mathe, Y.; Thiébaut, R.; Stintzing, S. Validation of miR-31-3p expression to predict cetuximab efficacy when used as first-line treatment in RAS wild-type metastatic colorectal cancer. Clin. Cancer Res. 2019, 25, 134-141. [CrossRef] [PubMed]

13. Anandappa, G.; Lampis, A.; Cunningham, D.; Khan, K.H.; Kouvelakis, K.; Vlachogiannis, G.; Hedayat, S.; Tunariu, N.; Rao, S.; Watkins, D.; et al. miR-31-3p expression and benefit from anti-EGFR inhibitors in metastatic colorectal cancer patients enrolled in the prospective phase II PROSPECT-C trial. Clin. Cancer Res. 2019, 25, 3830-3838. [CrossRef] [PubMed]

14. Pugh, S.; Thiébaut, R.; Bridgewater, J.; Grisoni, M.-L.; Moutasim, K.; Rousseau, F.; Thomas, G.J.; Griffiths, G.; Liebaert, F.; Primrose, J.; et al. Association between miR-31-3p expression and cetuximab efficacy in patients with KRAS wild-type metastatic colorectal cancer: A post-hoc analysis of the new EPOC trial. Oncotarget 2017, 8, 93856-93866. [CrossRef]

15. Taieb, J.; Tabernero, J.; Mini, E.; Subtil, F.; Folprecht, G.; Van Laethem, J.-L.; Thaler, J.; Bridgewater, J.; Petersen, L.N.; Blons, H.; et al. Oxaliplatin, fluorouracil, and leucovorin with or without cetuximab in patients with resected stage III colon cancer (PETACC-8): An open-label, randomised phase 3 trial. Lancet Oncol. 2014, 15, 862-873. [CrossRef]

16. Bridgewater, J.A.; Pugh, S.A.; Maishman, T.; Eminton, Z.; Mellor, J.; Whitehead, A.; Stanton, L.; Radford, M.; Corkhill, A.; Griffiths, G.O.; et al. Systemic chemotherapy with or without cetuximab in patients with resectable colorectal liver metastasis (New EPOC): Long-term results of a multicentre, randomised, controlled, phase 3 trial. Lancet Oncol. 2020, 21, 398-411. [CrossRef]

17. Gholami, S.; Grothey, A. EGFR antibodies in resectable metastatic colorectal liver metastasis: More harm than benefit? Lancet Oncol. 2020, 21, 324-326. [CrossRef]

18. Modest, D.P.; Martens, U.M.; Riera-Knorrenschild, J.; Greeve, J.; Florschütz, A.; Wessendorf, S.; Ettrich, T.; Kanzler, S.; Nörenberg, D.; Ricke, J.; et al. FOLFOXIRI plus panitumumab as first-line treatment of RAS wild-type metastatic colorectal cancer: The randomized, open-label, phase II VOLFI study (AIO KRK0109). J. Clin. Oncol. 2019, 37, 3401-3411. [CrossRef]

19. Douillard, J.-Y.; Oliner, K.S.; Siena, S.; Tabernero, J.; Burkes, R.; Barugel, M.; Humblet, Y.; Bodoky, G.; Cunningham, D.; Jassem, J.; et al. Panitumumab-FOLFOX4 treatment and RAS mutations in colorectal cancer. N. Engl. J. Med. 2013, 369, 1023-1034. [CrossRef]

20. Van Cutsem, E.; Köhne, C.-H.; Hitre, E.; Zaluski, J.; Chang Chien, C.-R.; Makhson, A.; D’Haens, G.; Pintér, T.; Lim, R.; Bodoky, G.; et al. Cetuximab and chemotherapy as initial treatment for metastatic colorectal cancer. N. Engl. J. Med. 2009, 360, 1408-1417. [CrossRef] 
21. Bokemeyer, C.; Bondarenko, I.; Makhson, A.; Hartmann, J.T.; Aparicio, J.; de Braud, F.; Donea, S.; Ludwig, H.; Schuch, G.; Stroh, C.; et al. Fluorouracil, leucovorin, and oxaliplatin with and without cetuximab in the First-line treatment of metastatic colorectal cancer. J. Clin. Oncol. 2008, 27, 663-671. [CrossRef] [PubMed]

22. Moosmann, N.; von Weikersthal, L.F.; Vehling-Kaiser, U.; Stauch, M.; Hass, H.G.; Dietzfelbinger, H.; Oruzio, D.; Klein, S.; Zellmann, K.; Decker, T.; et al. Cetuximab plus Capecitabine and irinotecan compared with cetuximab plus capecitabine and oxaliplatin as first-line treatment for patients with metastatic colorectal cancer: AIO KRK-0104-A Randomized trial of the german AIO CRC study group. J. Clin. Oncol. 2011, 29, 1050-1058. [CrossRef] [PubMed]

23. Bokemeyer, C.; Cutsem, E.V.; Rougier, P.; Ciardiello, F.; Heeger, S.; Schlichting, M.; Celik, I.; Köhne, C.-H. Addition of cetuximab to chemotherapy as first-line treatment for KRAS wild-type metastatic colorectal cancer: Pooled analysis of the CRYSTAL and OPUS randomised clinical trials. Eur. J. Cancer 2012, 48, 1466-1475. [CrossRef] [PubMed]

24. André, T.; Blons, H.; Mabro, M.; Chibaudel, B.; Bachet, J.-B.; Tournigand, C.; Bennamoun, M.; Artru, P.; Nguyen, S.; Ebenezer, C.; et al. Panitumumab combined with irinotecan for patients with KRAS wild-type metastatic colorectal cancer refractory to standard chemotherapy: A GERCOR efficacy, tolerance, and translational molecular study. Ann. Oncol. 2013, 24, 412-419. [CrossRef]

25. Seymour, M.T.; Brown, S.R.; Middleton, G.; Maughan, T.; Richman, S.; Gwyther, S.; Lowe, C.; Seligmann, J.F.; Wadsley, J.; Maisey, N.; et al. Panitumumab and irinotecan versus irinotecan alone for patients with KRAS wild-type, fluorouracil-resistant advanced colorectal cancer (PICCOLO): A prospectively stratified randomised trial. Lancet Oncol. 2013, 14, 749-759. [CrossRef]

26. Cunningham, D.; Humblet, Y.; Siena, S.; Khayat, D.; Bleiberg, H.; Santoro, A.; Bets, D.; Mueser, M.; Harstrick, A.; Verslype, C.; et al. Cetuximab monotherapy and cetuximab plus irinotecan in irinotecan-refractory metastatic colorectal cancer. N. Engl. J. Med. 2004, 351, 337-345. [CrossRef]

27. Carrato, A.; Abad, A.; Massuti, B.; Grávalos, C.; Escudero, P.; Longo-Muñoz, F.; Manzano, J.-L.; Gómez, A.; Safont, M.J.; Gallego, J.; et al. First-line panitumumab plus FOLFOX4 or FOLFIRI in colorectal cancer with multiple or unresectable liver metastases: A randomised, phase II trial (PLANET-TTD). Eur. J. Cancer 2017, 81, 191-202. [CrossRef]

28. Jonker, D.J.; O'Callaghan, C.J.; Karapetis, C.S.; Zalcberg, J.R.; Tu, D.; Au, H.-J.; Berry, S.R.; Krahn, M.; Price, T.; Simes, R.J.; et al. Cetuximab for the treatment of colorectal cancer. N. Engl. J. Med. 2007, 357, 2040-2048. [CrossRef]

29. Sobrero, A.F.; Maurel, J.; Fehrenbacher, L.; Scheithauer, W.; Abubakr, Y.A.; Lutz, M.P.; Vega-Villegas, M.E.; Eng, C.; Steinhauer, E.U.; Prausova, J.; et al. EPIC: Phase III trial of cetuximab plus irinotecan after fluoropyrimidine and oxaliplatin failure in patients with metastatic colorectal cancer. J. Clin. Oncol. 2008, 26, 2311-2319. [CrossRef]

30. Tveit, K.M.; Guren, T.; Glimelius, B.; Pfeiffer, P.; Sorbye, H.; Pyrhonen, S.; Sigurdsson, F.; Kure, E.; Ikdahl, T.; Skovlund, E.; et al. Phase III trial of cetuximab with continuous or intermittent fluorouracil, leucovorin, and oxaliplatin (Nordic FLOX) versus FLOX alone in first-line treatment of metastatic colorectal cancer: The NORDIC-VII study. J. Clin. Oncol. 2012, 30, 1755-1762. [CrossRef]

31. Maughan, T.S.; Adams, R.A.; Smith, C.G.; Meade, A.M.; Seymour, M.T.; Wilson, R.H.; Idziaszczyk, S.; Harris, R.; Fisher, D.; Kenny, S.L.; et al. Addition of cetuximab to oxaliplatin-based first-line combination chemotherapy for treatment of advanced colorectal cancer: Results of the randomised phase 3 MRC COIN trial. Lancet 2011, 377, 2103-2114. [CrossRef]

32. Qin, S.; Li, J.; Wang, L.; Xu, J.; Cheng, Y.; Bai, Y.; Li, W.; Xu, N.; Lin, L.-Z.; Wu, Q.; et al. Efficacy and tolerability of first-line cetuximab plus leucovorin, fluorouracil, and oxaliplatin (FOLFOX-4) versus FOLFOX-4 in patients with RAS wild-type metastatic colorectal cancer: The open-label, randomized, phase III TAILOR trial. J. Clin. Oncol. 2018, 36, 3031-3039. [CrossRef] [PubMed]

33. Price, T.J.; Peeters, M.; Kim, T.W.; Li, J.; Cascinu, S.; Ruff, P.; Suresh, A.S.; Thomas, A.; Tjulandin, S.; Zhang, K.; et al. Panitumumab versus cetuximab in patients with chemotherapy-refractory wild-type KRAS exon 2 metastatic colorectal cancer (ASPECCT): A randomised, multicentre, open-label, non-inferiority phase 3 study. Lancet Oncol. 2014, 15, 569-579. [CrossRef]

34. Tejpar, S.; Stintzing, S.; Ciardiello, F.; Tabernero, J.; Van Cutsem, E.; Beier, F.; Esser, R.; Lenz, H.-J.; Heinemann, V. Prognostic and predictive relevance of primary tumor location in patients with RAS wild-type metastatic colorectal cancer: Retrospective analyses of the CRYSTAL and FIRE-3 trials. JAMA Oncol. 2016. [CrossRef] 
35. Arnold, D.; Lueza, B.; Douillard, J.-Y.; Peeters, M.; Lenz, H.-J.; Venook, A.; Heinemann, V.; Van Cutsem, E.; Pignon, J.-P.; Tabernero, J.; et al. Prognostic and predictive value of primary tumour side in patients with RAS wild-type metastatic colorectal cancer treated with chemotherapy and EGFR directed antibodies in six randomized trials. Ann. Oncol. 2017, 28, 1713-1729. [CrossRef]

36. Yin, J.; Cohen, R.; Jin, Z.; Liu, H.; Pederson, L.; Adams, R.; Maughan, T.; Venook, A.P.; Van Cutsem, E.; Cremolini, C.; et al. Prognostic and predictive impact of primary tumor sidedness in first-line trials for advanced colorectal cancer: An analysis of 7,828 patients in the ARCAD database. J. Clin. Oncol. 2020, 38, 188. [CrossRef]

37. Benson, A.B.; Venook, A.P.; Al-Hawary, M.M.; Cederquist, L.; Chen, Y.-J.; Ciombor, K.K.; Cohen, S.; Cooper, H.S.; Deming, D.; Engstrom, P.F.; et al. NCCN guidelines insights: Colon cancer, version 2.2018. J. Natl. Compr. Cancer Netw. 2018, 16, 359-369. [CrossRef]

38. Mauri, G.; Pizzutilo, E.G.; Amatu, A.; Bencardino, K.; Palmeri, L.; Bonazzina, E.F.; Tosi, F.; Carlo Stella, G.; Burrafato, G.; Scaglione, F.; et al. Retreatment with anti-EGFR monoclonal antibodies in metastatic colorectal cancer: Systematic review of different strategies. Cancer Treat. Rev. 2019, 73, 41-53. [CrossRef]

39. Tonini, G.; Imperatori, M.; Vincenzi, B.; Frezza, A.M.; Santini, D. Rechallenge therapy and treatment holiday: Different strategies in management of metastatic colorectal cancer. J. Exp. Clin. Cancer Res. 2013, 32, 92. [CrossRef]

40. Siravegna, G.; Mussolin, B.; Buscarino, M.; Corti, G.; Cassingena, A.; Crisafulli, G.; Ponzetti, A.; Cremolini, C.; Amatu, A.; Lauricella, C.; et al. Clonal evolution and resistance to EGFR blockade in the blood of colorectal cancer patients. Nat. Med. 2015, 21, 827. [CrossRef]

41. Martinelli, E.; Ciardiello, D.; Martini, G.; Troiani, T.; Cardone, C.; Vitiello, P.P.; Normanno, N.; Rachiglio, A.M.; Maiello, E.; Latiano, T.; et al. Implementing anti-epidermal growth factor receptor (EGFR) therapy in metastatic colorectal cancer: Challenges and future perspectives. Ann. Oncol. 2020, 31, 30-40. [CrossRef] [PubMed]

42. Cremolini, C.; Rossini, D.; Dell'Aquila, E.; Lonardi, S.; Conca, E.; Del Re, M.; Busico, A.; Pietrantonio, F.; Danesi, R.; Aprile, G.; et al. Rechallenge for patients with RAS and BRAF wild-type metastatic colorectal cancer with acquired resistance to first-line cetuximab and irinotecan: A phase 2 single-arm clinical trial. JAMA Oncol. 2019, 5, 343-350. [CrossRef] [PubMed]

43. Venderbosch, S.; Nagtegaal, I.D.; Maughan, T.S.; Smith, C.G.; Cheadle, J.P.; Fisher, D.; Kaplan, R.; Quirke, P.; Seymour, M.T.; Richman, S.D.; et al. Mismatch repair status and BRAF mutation status in metastatic colorectal cancer patients: A pooled analysis of the CAIRO, CAIRO2, COIN, and FOCUS studies. Clin. Cancer Res. 2014, 20, 5322-5330. [CrossRef] [PubMed]

44. Jones, J.C.; Renfro, L.A.; Al-Shamsi, H.O.; Schrock, A.B.; Rankin, A.; Zhang, B.Y.; Kasi, P.M.; Voss, J.S.; Leal, A.D.; Sun, J.; et al. Non-V600 BRAF mutations define a clinically distinct molecular subtype of metastatic colorectal cancer. J. Clin. Oncol. 2017, 35, 2624. [CrossRef]

45. Yaeger, R.; Kotani, D.; Mondaca, S.; Parikh, A.R.; Bando, H.; Van Seventer, E.E.; Taniguchi, H.; Zhao, H.; Thant, C.N.; de Stanchina, E.; et al. Response to anti-EGFR therapy in patients with BRAF non-V600-mutant metastatic colorectal cancer. Clin. Cancer Res. 2019, 25, 7089-7097. [CrossRef] [PubMed]

46. Johnson, B.; Loree, J.M.; Morris, V.K.; Dasari, A.; Pant, S.; Raghav, K.P.S.; Kopetz, S. Activity of EGFR inhibition in atypical (non-V600E) BRAF-mutated metastatic colorectal cancer. J. Clin. Oncol. 2019, 37, 596. [CrossRef]

47. Pagani, F.; Randon, G.; Guarini, V.; Raimondi, A.; Prisciandaro, M.; Lobefaro, R.; Di Bartolomeo, M.; Sozzi, G.; de Braud, F.; Gasparini, P.; et al. The landscape of actionable gene fusions in colorectal cancer. Int. J. Mol. Sci. 2019, 20, 5319. [CrossRef]

48. Cocco, E.; Benhamida, J.; Middha, S.; Zehir, A.; Mullaney, K.; Shia, J.; Yaeger, R.; Zhang, L.; Wong, D.; Villafania, L.; et al. Colorectal carcinomas containing hypermethylated MLH1 promoter and wild-type $B R A F / K R A S$ are enriched for targetable kinase fusions. Cancer Res. 2019, 79, 1047-1053. [CrossRef]

49. Tran, B.; Kopetz, S.; Tie, J.; Gibbs, P.; Jiang, Z.-Q.; Lieu, C.H.; Agarwal, A.; Maru, D.M.; Sieber, O.; Desai, J. Impact of $B R A F$ mutation and microsatellite instability on the pattern of metastatic spread and prognosis in metastatic colorectal cancer. Cancer 2011, 117, 4623-4632. [CrossRef] 
50. Overman, M.; Lonardi, S.; Wong, K.; Lenz, H.; Gelsomino, F.; Aglietta, M.; Morse, M.; Van Cutsem, E.; McDermott, R.; Hill, A.; et al. Durable clinical benefit with nivolumab plus ipilimumab in DNA mismatch repair-deficient/microsatellite instability-high metastatic colorectal. Cancer J. Clin. Oncol. 2018, 36, 773-779. [CrossRef]

51. Morris, V.; Overman, M.J.; Jiang, Z.-Q.; Garrett, C.; Agarwal, S.; Eng, C.; Kee, B.; Fogelman, D.; Dasari, A.; Wolff, R.; et al. Progression-free survival remains poor over sequential lines of systemic therapy in patients with BRAF-mutated colorectal cancer. Clin. Color. Cancer 2014, 13, 164-171. [CrossRef] [PubMed]

52. Seligmann, J.F.; Fisher, D.; Smith, C.G.; Richman, S.D.; Elliott, F.; Brown, S.; Adams, R.; Maughan, T.; Quirke, P.; Cheadle, J.; et al. Investigating the poor outcomes of BRAF-mutant advanced colorectal cancer: Analysis from 2530 patients in randomised clinical trials. Ann. Oncol. 2017, 28, 562-568. [CrossRef] [PubMed]

53. de la Fouchardière, C.; Cohen, R.; Malka, D.; Guimbaud, R.; Bourien, H.; Lièvre, A.; Cacheux, W.; Artru, P.; François, E.; Gilabert, M.; et al. Characteristics of $B R A F^{\mathrm{V} 600 \mathrm{E}}$ mutant, deficient mismatch repair/proficient mismatch repair, metastatic colorectal cancer: A multicenter series of 287 patients. Oncologist 2019, 24, e1331-e1340. [CrossRef] [PubMed]

54. Loupakis, F.; Cremolini, C.; Antoniotti, C.; Lonardi, S.; Ronzoni, M.; Zaniboni, A.; Tonini, G.; Salvatore, L.; Chiara, S.; Carlomagno, C.; et al. FOLFOXIRI plus bevacizumab versus FOLFIRI plus bevacizumab as initial treatment for metastatic colorectal cancer (TRIBE study): Updated survival results and final molecular subgroups analyses. J. Clin. Oncol. 2015, 33, 3510. [CrossRef]

55. Cremolini, C.; Antoniotti, C.; Lonardi, S.; Rossini, D.; Morano, F.; Cordio, S.; Bergamo, F.; Marmorino, F.; Maiello, E.; Passardi, A.; et al. Updated results of TRIBE2, a phase III, randomized strategy study by GONO in the 1st- and 2nd-line treatment of unresectable mCRC. Ann. Oncol. 2019, 37, 3058. [CrossRef]

56. Hurwitz, H.; Fehrenbacher, L.; Novotny, W.; Cartwright, T.; Hainsworth, J.; Heim, W.; Berlin, J.; Baron, A.; Griffing, S.; Holmgren, E.; et al. Bevacizumab plus irinotecan, fluorouracil, and leucovorin for metastatic colorectal cancer. N. Engl. J. Med. 2004, 350, 2335-2342. [CrossRef]

57. Price, T.J.; Hardingham, J.E.; Lee, C.K.; Weickhardt, A.; Townsend, A.R.; Wrin, J.W.; Chua, A.; Shivasami, A.; Cummins, M.M.; Murone, C.; et al. Impact of KRAS and BRAF gene mutation status on outcomes from the phase III AGITG MAX trial of capecitabine alone or in combination with bevacizumab and mitomycin in advanced colorectal cancer. J. Clin. Oncol. 2011, 29, 2675-2682. [CrossRef]

58. Wirapati, P.; Pomella, V.; VandenBosch, B.; Kerr, P.; Maiello, E.; Grahame, M.J.; Curca, R.-O.D.; Karthaus, M.; Bridgewater, J.A.; Mihailov, A.C.; et al. LBA-005VELOUR trial biomarkers update: Impact of RAS, BRAF, and sidedness on aflibercept activity. Ann. Oncol. 2017, 28, iii151-iii152. [CrossRef]

59. Yoshino, T.; Portnoy, D.C.; Obermannová, R.; Bodoky, G.; Prausová, J.; Garcia-Carbonero, R.; Ciuleanu, T.; García-Alfonso, P.; Cohn, A.L.; Van Cutsem, E.; et al. Biomarker analysis beyond angiogenesis: RAS/RAF mutation status, tumour sidedness, and second-line ramucirumab efficacy in patients with metastatic colorectal carcinoma from RAISE-a global phase III study. Ann. Oncol. 2019, 30, 124-131. [CrossRef]

60. Gelsomino, F.; Casadei-Gardini, A.; Rossini, D.; Boccaccino, A.; Masi, G.; Cremolini, C.; Spallanzani, A.; Viola, M.G.; Garajovà, I.; Salati, M.; et al. The role of anti-angiogenics in pre-treated metastatic BRAF-mutant colorectal cancer: A pooled analysis. Cancers 2020, 12, 1022. [CrossRef]

61. Pietrantonio, F.; Petrelli, F.; Coinu, A.; Di Bartolomeo, M.; Borgonovo, K.; Maggi, C.; Cabiddu, M.; Iacovelli, R.; Bossi, I.; Lonati, V.; et al. Predictive role of $B R A F$ mutations in patients with advanced colorectal cancer receiving cetuximab and panitumumab: A meta-analysis. Eur. J. Cancer 2015, 51, 587-594. [CrossRef] [PubMed]

62. Rowland, A.; Dias, M.M.; Wiese, M.D.; Kichenadasse, G.; McKinnon, R.A.; Karapetis, C.S.; Sorich, M.J. Meta-analysis of BRAF mutation as a predictive biomarker of benefit from anti-EGFR monoclonal antibody therapy for RAS wild-type metastatic colorectal cancer. Br. J. Cancer 2015, 112, 1888-1894. [CrossRef] [PubMed]

63. Stintzing, S.; Miller-Phillips, L.; Modest, D.P.; Fischer von Weikersthal, L.; Decker, T.; Kiani, A.; Vehling-Kaiser, U.; Al-Batran, S.-E.; Heintges, T.; Kahl, C.; et al. Impact of BRAF and RAS mutations on first-line efficacy of FOLFIRI plus cetuximab versus FOLFIRI plus bevacizumab: Analysis of the FIRE-3 (AIO KRK-0306) study. Eur. J. Cancer 2017, 79, 50-60. [CrossRef] [PubMed]

64. Kopetz, S.; Grothey, A.; Yaeger, R.; Van Cutsem, E.; Desai, J.; Yoshino, T.; Wasan, H.; Ciardiello, F.; Loupakis, F.; Hong, Y.S.; et al. Encorafenib, binimetinib, and cetuximab in BRAF V600E-mutated colorectal cancer. N. Engl. J. Med. 2019, 381, 1632-1643. [CrossRef] 
65. Corcoran, R.B.; Ebi, H.; Turke, A.B.; Coffee, E.M.; Nishino, M.; Cogdill, A.P.; Brown, R.D.; Della Pelle, P.; Dias-Santagata, D.; Hung, K.E.; et al. EGFR-mediated re-activation of MAPK signaling contributes to insensitivity of BRAF mutant colorectal cancers to RAF inhibition with vemurafenib. Cancer Discov. 2012, 2, 227-235. [CrossRef]

66. Yaeger, R.; Cercek, A.; O’Reilly, E.M.; Reidy, D.L.; Kemeny, N.; Wolinsky, T.; Capanu, M.; Gollub, M.J.; Rosen, N.; Berger, M.F.; et al. Pilot trial of combined BRAF and EGFR inhibition in BRAF-mutant metastatic colorectal cancer patients. Clin. Cancer Res. 2015, 21, 1313-1320. [CrossRef]

67. Hong, D.S.; Morris, V.K.; El Osta, B.; Sorokin, A.V.; Janku, F.; Fu, S.; Overman, M.J.; Piha-Paul, S.; Subbiah, V.; Kee, B.; et al. Phase $1 \mathrm{~B}$ study of vemurafenib in combination with irinotecan and cetuximab in patients with metastatic colorectal cancer with BRAF V600E mutation. Cancer Discov. 2016, 6, 1352-1365. [CrossRef]

68. Van Geel, R.M.J.M.; Tabernero, J.; Elez, E.; Bendell, J.C.; Spreafico, A.; Schuler, M.; Yoshino, T.; Delord, J.-P.; Yamada, Y.; Lolkema, M.P.; et al. A phase Ib dose-escalation study of encorafenib and cetuximab with or without alpelisib in metastatic BRAF-mutant colorectal cancer. Cancer Discov. 2017, 7, 610-619. [CrossRef]

69. Kopetz, S.; McDonough, S.L.; Morris, V.K.; Lenz, H.-J.; Magliocco, A.M.; Atreya, C.E.; Diaz, L.A.; Allegra, C.J.; Wang, S.E.; Lieu, C.H.; et al. Randomized trial of irinotecan and cetuximab with or without vemurafenib in BRAF-mutant metastatic colorectal cancer (SWOG 1406). J. Clin. Oncol. 2017, 35, 520. [CrossRef]

70. Corcoran, R.B.; André, T.; Atreya, C.E.; Schellens, J.H.M.; Yoshino, T.; Bendell, J.C.; Hollebecque, A.; McRee, A.J.; Siena, S.; Middleton, G.; et al. Combined BRAF, EGFR, and MEK inhibition in patients with $B R A F^{\mathrm{V} 600 \mathrm{E}}$-mutant colorectal cancer. Cancer Discov. 2018, 8, 428-443. [CrossRef]

71. Kopetz, S.; Grothey, A.; Van Cutsem, E.; Yaeger, R.; Wasan, H.S.; Yoshino, T.; Desai, J.; Ciardiello, F.; Loupakis, F.; Hong, Y.S.; et al. Encorafenib plus cetuximab with or without binimetinib for BRAF V600E metastatic colorectal cancer: Updated survival results from a randomized, three-arm, phase III study versus choice of either irinotecan or FOLFIRI plus cetuximab (BEACON CRC). J. Clin. Oncol. 2020, 38, 4001. [CrossRef]

72. Kopetz, S.; Grothey, A.; Van Cutsem, E.; Yaeger, R.; Wasan, H.S.; Yoshino, T.; Desai, J.; Ciardiello, F.; Loupakis, F.; Hong, Y.S.; et al. Encorafenib plus cetuximab with or without binimetinib for BRAF ${ }^{\mathrm{V} 600 \mathrm{E}}$-mutant metastatic colorectal cancer: Quality-of-life results from a randomized, three-arm, phase III study versus the choice of either irinotecan or FOLFIRI plus cetuximab (BEACON CRC). J. Clin. Oncol. 2020, 38, 8. [CrossRef]

73. Battaglin, F.; Puccini, A.; Intini, R.; Schirripa, M.; Ferro, A.; Bergamo, F.; Lonardi, S.; Zagonel, V.; Lenz, H.-J.; Loupakis, F. The role of tumor angiogenesis as a therapeutic target in colorectal cancer. Expert Rev. Anticancer Ther. 2018, 18, 251-266. [CrossRef] [PubMed]

74. Wirapati, P.; Pomella, V.; Kerr, P.; Maiello, E.; Jeffery, G.; Curca, R.-O.; Karthaus, M.; Bridgewater, J.; Mihailov, A. Velour trial biomarkers update: Impact of RAS, BRAF, and sidedness on aflibercept activity. J. Clin. Oncol. 2017, 35, 3538. [CrossRef]

75. Nagasaka, M.; Li, Y.; Sukari, A.; Ou, S.-H.I.; Al-Hallak, M.N.; Azmi, A.S. KRAS G12C Game of Thrones, which direct KRAS inhibitor will claim the iron throne? Cancer Treat. Rev. 2020, 84, 101974. [CrossRef]

76. Fakih, M.; Desai, J.; Kuboki, Y.; Strickler, J.H.; Price, T.J.; Durm, G.A.; Falchook, G.S.; Denlinger, C.S.; Krauss, J.C.; Shapiro, G.; et al. CodeBreak 100: Activity of AMG 510, a novel small molecule inhibitor of KRASG12C, in patients with advanced colorectal cancer. J. Clin. Oncol. 2020, 38, 4018. [CrossRef]

77. Colle, R.; Cohen, R.; Cochereau, D.; Duval, A.; Lascols, O.; Lopez-Trabada, D.; Afchain, P.; Trouilloud, I.; Parc, Y.; Lefevre, J.; et al. Immunotherapy and patients treated for cancer with microsatellite instability. Bull. Cancer 2017, 104, 42-51. [CrossRef]

78. André, T.; de Gramont, A.; Vernerey, D.; Chibaudel, B.; Bonnetain, F.; Tijeras-Raballand, A.; Scriva, A.; Hickish, T.; Tabernero, J.; Van Laethem, J.; et al. Adjuvant fluorouracil, leucovorin, and oxaliplatin in stage II to III colon cancer: Updated 10-year survival and outcomes According to BRAF mutation and mismatch repair status of the mosaic study. J. Clin. Oncol. 2015, 33, 4176-4187. [CrossRef]

79. Sargent, D.J.; Marsoni, S.; Monges, G.; Thibodeau, S.N.; Labianca, R.; Hamilton, S.R.; French, A.J.; Kabat, B.; Foster, N.R.; Torri, V.; et al. Defective mismatch repair as a predictive marker for lack of efficacy of fluorouracil-based adjuvant therapy in colon cancer. J. Clin. Oncol. 2010, 28, 3219-3226. [CrossRef]

80. Zaanan, A.; Shi, Q.; Taieb, J.; Alberts, S.R.; Meyers, J.P.; Smyrk, T.C.; Julie, C.; Zawadi, A.; Tabernero, J.; Mini, E.; et al. Role of deficient DNA mismatch repair status in patients with stage III colon cancer treated with FOLFOX adjuvant chemotherapy: A pooled analysis from 2 randomized clinical trials. JAMA Oncol. 2018, 4, 379-383. [CrossRef] 
81. Innocenti, F.; Ou, F.-S.; Qu, X.; Zemla, T.J.; Niedzwiecki, D.; Tam, R.; Mahajan, S.; Goldberg, R.M.; Bertagnolli, M.M.; Blanke, C.D.; et al. Mutational analysis of patients with colorectal cancer in CALGB/SWOG 80405 identifies new roles of microsatellite instability and tumor mutational burden for patient outcome. J. Clin. Oncol. 2019, 37, 1217. [CrossRef] [PubMed]

82. Tougeron, D.; Sueur, B.; Zaanan, A.; Fouchardiére, C.; Sefrioui, D.; Lecomte, T.; Aparicio, T.; Des Guetz, G.; Artru, P.; Hautefeuille, V.; et al. Prognosis and chemosensitivity of deficient MMR phenotype in patients with metastatic colorectal cancer: An AGEO retrospective multicenter study. Int. J. Cancer 2020, 147, $285-296$. [CrossRef] [PubMed]

83. Taieb, J.; Shi, Q.; Pederson, L.; Alberts, S.; Wolmark, N.; Van Cutsem, E.; de Gramont, A.; Kerr, R.; Grothey, A.; Lonardi, S.; et al. Prognosis of microsatellite instability and/or mismatch repair deficiency stage III colon cancer patients after disease recurrence following adjuvant treatment: Results of an ACCENT pooled analysis of seven studies. Ann. Oncol. 2019, 30, 1466-1471. [CrossRef] [PubMed]

84. Stadler, Z.K.; Battaglin, F.; Middha, S.; Hechtman, J.F.; Tran, C.; Cercek, A.; Yaeger, R.; Segal, N.H.; Varghese, A.M.; Reidy-Lagunes, D.L.; et al. Reliable detection of mismatch repair deficiency in colorectal cancers using mutational load in next-generation sequencing panels. J. Clin. Oncol. 2016, 34, 2141-2147. [CrossRef] [PubMed]

85. Muzny, D.M.; Bainbridge, M.N.; Chang, K.; Dinh, H.H.; Drummond, J.A.; Fowler, G.; Kovar, C.L.; Lewis, L.R.; Morgan, M.B.; Newsham, I.F.; et al. Comprehensive molecular characterization of human colon and rectal cancer. Nature 2012, 487, 330-337. [CrossRef]

86. Maby, P.; Tougeron, D.; Hamieh, M.; Mlecnik, B.; Kora, H.; Bindea, G.; Angell, H.K.; Fredriksen, T.; Elie, N.; Fauquembergue, E.; et al. Correlation between density of CD8+ T-cell infiltrate in microsatellite unstable colorectal cancers and frameshift mutations: A rationale for personalized immunotherapy. Cancer Res. 2015, 75, 3446-3455. [CrossRef]

87. Marisa, L.; Svrcek, M.; Collura, A.; Becht, E.; Cervera, P.; Wanherdrick, K.; Buhard, O.; Goloudina, A.; Jonchère, V.; Selves, J.; et al. The balance between cytotoxic T-cell lymphocytes and immune checkpoint expression in the prognosis of colon tumors. J. Natl. Cancer Inst. 2018, 110. [CrossRef]

88. Llosa, N.J.; Cruise, M.; Tam, A.; Wicks, E.C.; Hechenbleikner, E.M.; Taube, J.M.; Blosser, R.L.; Fan, H.; Wang, H.; Luber, B.S.; et al. The vigorous immune microenvironment of microsatellite instable colon cancer is balanced by multiple counter-inhibitory checkpoints. Cancer Discov. 2015, 5, 43-51. [CrossRef]

89. Le, D.T.; Kim, T.W.; Van Cutsem, E.; Geva, R.; Jäger, D.; Hara, H.; Burge, M.; O’Neil, B.; Kavan, P.; Yoshino, T;; et al. Phase II open-label study of pembrolizumab in treatment-refractory, microsatellite instability-high/mismatch repair-deficient metastatic colorectal cancer: KEYNOTE-164. J. Clin. Oncol. 2019, 38, 11-19. [CrossRef]

90. Le, D.T.; Durham, J.N.; Smith, K.N.; Wang, H.; Bartlett, B.R.; Aulakh, L.K.; Lu, S.; Kemberling, H.; Wilt, C.; Luber, B.S.; et al. Mismatch repair deficiency predicts response of solid tumors to PD-1 blockade. Science 2017, 357, 409-413. [CrossRef]

91. André, T.; Berton, D.; de Braud, F.; Curigliano, G.; Guo, W.; Danaee, H.; Lu, S.; Im, E.; Starling, N. Safety and efficacy of anti-PD-1 antibody dostarlimab in patients (pts) with mismatch repair deficient (dMMR) GI cancers. J. Clin. Oncol. 2020, 38, 218. [CrossRef]

92. Kim, J.H.; Kim, S.Y.; Baek, J.Y.; Cha, Y.J.; Ahn, J.B.; Kim, H.S.; Lee, K.-W.; Kim, J.-W.; Kim, T.-Y.; Chang, W.J.; et al. A Phase II study of avelumab monotherapy in patients with mismatch repair-deficient/microsatellite instability-high or POLE-mutated metastatic or unresectable colorectal cancer. Cancer Res. Treat. 2020. [CrossRef] [PubMed]

93. Segal, N.H.; Wainberg, Z.A.; Overman, M.J.; Ascierto, P.A.; Arkenau, H.-T.; Butler, M.O.; Eder, J.P.; Kim, D.-W.; Cunningham, D.; Khleif, S.N.; et al. Safety and clinical activity of durvalumab monotherapy in patients with microsatellite instability-high (MSI-H) tumors. J. Clin. Oncol. 2019, 37, 670. [CrossRef]

94. Le, D.T.; Uram, J.N.; Wang, H.; Bartlett, B.R.; Kemberling, H.; Eyring, A.D.; Skora, A.D.; Luber, B.S.; Azad, N.S.; Laheru, D.; et al. PD-1 Blockade in Tumors with Mismatch-Repair Deficiency. N. Engl. J. Med. 2015, 372, 2509-2520. [CrossRef]

95. Lenz, H.-J.J.; Van Cutsem, E.; Limon, M.L.; Wong, K.Y.; Hendlisz, A.; Aglietta, M.; Garcia-Alfonso, P.; Neyns, B.; Luppi, G.; Cardin, D.; et al. LBA18_PRDurable clinical benefit with nivolumab (NIVO) plus low-dose ipilimumab (IPI) as first-line therapy in microsatellite instability-high/mismatch repair deficient (MSI-H/dMMR) metastatic colorectal cancer (mCRC). Ann. Oncol. 2018, 29. [CrossRef] 
96. Andre, T.; Shiu, K.-K.; Kim, T.W.; Jensen, B.V.; Jensen, L.H.; Punt, C.J.A.; Smith, D.M.; Garcia-Carbonero, R.; Benavides, M.; Gibbs, P.; et al. Pembrolizumab versus chemotherapy for microsatellite instability-high/mismatch repair deficient metastatic colorectal cancer: The phase 3 KEYNOTE-177 Study. J. Clin. Oncol. 2020, 38, LBA4. [CrossRef]

97. Chalabi, M.; Fanchi, L.F.; Dijkstra, K.K.; Van den Berg, J.G.; Aalbers, A.G.; Sikorska, K.; Lopez-Yurda, M.; Grootscholten, C.; Beets, G.L.; Snaebjornsson, P.; et al. Neoadjuvant immunotherapy leads to pathological responses in MMR-proficient and MMR-deficient early-stage colon cancers. Nat. Med. 2020. [CrossRef]

98. Loupakis, F.; Depetris, I.; Biason, P.; Intini, R.; Prete, A.A.; Leone, F.; Lombardi, P.; Filippi, R.; Spallanzani, A.; Cascinu, S.; et al. Prediction of benefit from checkpoint inhibitors in mismatch repair deficient metastatic colorectal cancer: Role of tumor infiltrating lymphocytes. Oncologist 2020. [CrossRef]

99. Cohen, R.; Hain, E.; Buhard, O.; Guilloux, A.; Bardier, A.; Kaci, R.; Bertheau, P.; Renaud, F.; Bibeau, F.; Fléjou, J.; et al. Association of primary resistance to immune checkpoint inhibitors in metastatic colorectal cancer with misdiagnosis of microsatellite instability or mismatch repair deficiency status. JAMA Oncol. 2018. [CrossRef]

100. Middha, S.; Yaeger, R.; Shia, J.; Stadler, Z.K.; King, S.; Guercio, S.; Paroder, V.; Bates, D.D.B.; Rana, S.; Diaz, L.A.; et al. Majority of B2M-mutant and -deficient colorectal carcinomas achieve clinical benefit from immune checkpoint inhibitor therapy and are microsatellite instability-high. J. Clin. Oncol. 2019, 3. [CrossRef]

101. Shin, D.S.; Zaretsky, J.M.; Escuin-Ordinas, H.; Garcia-Diaz, A.; Hu-Lieskovan, S.; Kalbasi, A.; Grasso, C.S.; Hugo, W.; Sandoval, S.; Torrejon, D.Y; et al. Primary resistance to PD-1 blockade mediated by JAK1/2 mutations. Cancer Discov. 2017, 7, 188-201. [CrossRef]

102. Schrock, A.B.; Ouyang, C.; Sandhu, J.; Sokol, E.; Jin, D.; Ross, J.S.; Miller, V.A.; Lim, D.; Amanam, I.; Chao, J.; et al. Tumor mutational burden is predictive of response to immune checkpoint inhibitors in MSI-high metastatic colorectal cancer. Ann. Oncol. 2019, 30, 1096-1103. [CrossRef]

103. Mandal, R.; Samstein, R.M.; Lee, K.-W.; Havel, J.J.; Wang, H.; Krishna, C.; Sabio, E.Y.; Makarov, V.; Kuo, F.; Blecua, P.; et al. Genetic diversity of tumors with mismatch repair deficiency influences anti-PD-1 immunotherapy response. Science 2019, 364, 485-491. [CrossRef]

104. Richman, S.D.; Southward, K.; Chambers, P.; Cross, D.; Barrett, J.; Hemmings, G.; Taylor, M.; Wood, H.; Hutchins, G.; Foster, J.M.; et al. HER2 overexpression and amplification as a potential therapeutic target in colorectal cancer: Analysis of 3256 patients enrolled in the QUASAR, FOCUS and PICCOLO colorectal cancer trials. J. Pathol. 2016, 238, 562-570. [CrossRef]

105. Shimada, Y.; Yagi, R.; Kameyama, H.; Nagahashi, M.; Ichikawa, H.; Tajima, Y.; Okamura, T.; Nakano, M.; Nakano, M.; Sato, Y.; et al. Utility of comprehensive genomic sequencing for detecting HER2-positive colorectal cancer. Hum. Pathol. 2017, 66, 1-9. [CrossRef]

106. Nam, S.K.; Yun, S.; Koh, J.; Kwak, Y.; Seo, A.N.; Park, K.U.; Kim, D.-W.; Kang, S.-B.; Kim, W.H.; Lee, H.S. $B R A F$, PIK3CA, and HER2 oncogenic alterations according to KRAS mutation status in advanced colorectal cancers with distant metastasis. PLoS ONE 2016, 11, e0151865. [CrossRef]

107. Ross, J.S.; Fakih, M.; Ali, S.M.; Elvin, J.A.; Schrock, A.B.; Suh, J.; Vergilio, J.-A.; Ramkissoon, S.; Severson, E.; Daniel, S.; et al. Targeting HER2 in colorectal cancer: The landscape of amplification and short variant mutations in ERBB2 and ERBB3. Cancer 2018, 124, 1358-1373. [CrossRef]

108. Missiaglia, E.; Jacobs, B.; D’Ario, G.; Di Narzo, A.F.; Soneson, C.; Budinska, E.; Popovici, V.; Vecchione, L.; Gerster, S.; Yan, P.; et al. Distal and proximal colon cancers differ in terms of molecular, pathological, and clinical features. Ann. Oncol. 2014, 25, 1995-2001. [CrossRef]

109. Sartore-Bianchi, A.; Trusolino, L.; Martino, C.; Bencardino, K.; Lonardi, S.; Bergamo, F.; Zagonel, V.; Leone, F.; Depetris, I.; Martinelli, E.; et al. Dual-targeted therapy with trastuzumab and lapatinib in treatment-refractory, KRAS codon 12/13 wild-type, HER2-positive metastatic colorectal cancer (HERACLES): A proof-of-concept, multicentre, open-label, phase 2 trial. Lancet Oncol. 2016, 17, 738-746. [CrossRef]

110. Siena, S.; Sartore-Bianchi, A.; Marsoni, S.; Hurwitz, H.I.; McCall, S.J.; Penault-Llorca, F.; Srock, S.; Bardelli, A.; Trusolino, L. Targeting the human epidermal growth factor receptor 2 (HER2) oncogene in colorectal cancer. Ann. Oncol. 2018, 29, 1108-1119. [CrossRef]

111. Wang, G.; He, Y.; Sun, Y.; Wang, W.; Qian, X.; Yu, X.; Pan, Y. Prevalence, prognosis and predictive status of HER2 amplification in anti-EGFR-resistant metastatic colorectal cancer. Clin. Transl. Oncol. 2020, 22, 813-822. [CrossRef] 
112. Valtorta, E.; Martino, C.; Sartore-Bianchi, A.; Penaullt-Llorca, F.; Viale, G.; Risio, M.; Rugge, M.; Grigioni, W.; Bencardino, K.; Lonardi, S.; et al. Assessment of a HER2 scoring system for colorectal cancer: Results from a validation study. Mod. Pathol. 2015, 28, 1481-1491. [CrossRef]

113. Meric-Bernstam, F.; Hurwitz, H.; Raghav, K.P.S.; McWilliams, R.R.; Fakih, M.; VanderWalde, A.; Swanton, C.; Kurzrock, R.; Burris, H.; Sweeney, C.; et al. Pertuzumab plus trastuzumab for HER2-amplified metastatic colorectal cancer (MyPathway): An updated report from a multicentre, open-label, phase 2a, multiple basket study. Lancet Oncol. 2019, 20, 518-530. [CrossRef]

114. Strickler, J.H.; Zemla, T.; Ou, F.-S.; Cercek, A.; Wu, C.; Sanchez, F.A.; Hubbard, J.; Jaszewski, B.; Bandel, L.; Schweitzer, B.; et al. Trastuzumab and tucatinib for the treatment of HER2 amplified metastatic colorectal cancer (mCRC): Initial results from the MOUNTAINEER trial. Ann. Oncol. 2019, 30, v200. [CrossRef]

115. Sartore-Bianchi, A.; Martino, C.; Lonardi, S.; Fenocchio, E.; Amatu, A.; Ghezzi, S.; Zagonel, V.; Ciardiello, F.; Ardizzoni, A.; Tosi, F.; et al. Phase II study of pertuzumab and trastuzumab-emtansine (T-DM1) in patients with HER2-positive metastatic colorectal cancer: The HERACLES-B (HER2 Amplification for Colo-rectaL cancer Enhanced Stratification, cohort B) trial. Ann. Oncol. 2019, 30, v869-v870. [CrossRef]

116. Drilon, A.; Laetsch, T.W.; Kummar, S.; DuBois, S.G.; Lassen, U.N.; Demetri, G.D.; Nathenson, M.; Doebele, R.C.; Farago, A.F.; Pappo, A.S.; et al. Efficacy of larotrectinib in TRK fusion-positive cancers in adults and children. N. Engl. J. Med. 2018, 378, 731-739. [CrossRef]

117. Drilon, A.; Siena, S.; Ou, S.-H.I.; Patel, M.; Ahn, M.J.; Lee, J.; Bauer, T.M.; Farago, A.F.; Wheler, J.J.; Liu, S.V.; et al. Safety and antitumor activity of the multitargeted Pan-TRK, ROS1, and ALK inhibitor entrectinib: Combined results from two phase I trials (ALKA-372-001 and STARTRK-1). Cancer Discov. 2017, 7, 400-409. [CrossRef]

118. Solomon, J.P.; Benayed, R.; Hechtman, J.F.; Ladanyi, M. Identifying patients with NTRK fusion cancer. Ann. Oncol. 2019, 30 (Suppl. 8), viii16-viii22. [CrossRef]

119. Yoshino, T.; Pentheroudakis, G.; Mishima, S.; Overman, M.J.; Yeh, K.-H.; Baba, E.; Naito, Y.; Calvo, F.; Saxena, A.; Chen, L.-T.; et al. JSCO/ESMO/ASCO/JSMO/TOS: International expert consensus recommendations for tumour-agnostic treatments in patients with solid tumours with microsatellite instability or NTRK fusions. Ann. Oncol. 2020. [CrossRef]

120. Lasota, J.; Chłopek, M.; Lamoureux, J.; Christiansen, J.; Kowalik, A.; Wasag, B.; Felisiak-Gołąbek, A.; Agaimy, A.; Biernat, W.; Canzonieri, V.; et al. Colonic adenocarcinomas harboring NTRK fusion genes: A clinicopathologic and molecular genetic study of 16 cases and review of the literature. Am. J. Surg. Pathol. 2020, 44, 162-173. [CrossRef]

121. Pietrantonio, F.; Di Nicolantonio, F.; Schrock, A.B.; Lee, J.; Tejpar, S.; Sartore-Bianchi, A.; Hechtman, J.F.; Christiansen, J.; Novara, L.; Tebbutt, N.; et al. ALK, ROS1, and NTRK rearrangements in metastatic colorectal Cancer. J. Natl. Cancer Inst. 2017, 109. [CrossRef]

122. Okamura, R.; Boichard, A.; Kato, S.; Sicklick, J.K.; Bazhenova, L.; Kurzrock, R. Analysis of NTRK alterations in pan-cancer adult and pediatric malignancies: Implications for NTRK-targeted therapeutics. J. Clin. Oncol. 2018. [CrossRef]

123. Cocco, E.; Scaltriti, M.; Drilon, A. NTRK fusion-positive cancers and TRK inhibitor therapy. Nat. Rev. Clin. Oncol. 2018, 1. [CrossRef]

124. Chou, A.; Fraser, T.; Ahadi, M.; Fuchs, T.; Sioson, L.; Clarkson, A.; Sheen, A.; Singh, N.; Corless, C.L.; Gill, A.J. NTRK gene rearrangements are highly enriched in MLH1/PMS2 deficient, BRAF wild-type colorectal carcinomas-A study of 4569 cases. Mod. Pathol. 2019, 33, 1-9. [CrossRef]

(C) 2020 by the authors. Licensee MDPI, Basel, Switzerland. This article is an open access article distributed under the terms and conditions of the Creative Commons Attribution (CC BY) license (http://creativecommons.org/licenses/by/4.0/). 